\title{
STRUCTURAL ANALYSIS OF APARTMENT BUILDING WITH SPECIAL RESISTING FRAME SYSTEM
}

\author{
Sita Ramandhani Arumsari Susanto \\ Faculty of Engineering, Narotama University Surabaya \\ sitarmdh1@gmail.com \\ Koespiadi \\ Faculty of Engineering, Narotama University Surabaya
}

\begin{abstract}
Indonesia has a high earthquake risk, therefore several buildings in Indonesia are designed with seismic retention systems where the column structure is designed to be stronger than the beam. The calculation of apartment building structure in this final design is based on SNI 1726:2012 and SNI 2847:2013. The method used in this calculation is the Special Moment Resisting Frame System (SMRFS) because the building area is included in the category of $\mathrm{E}$ seismic design which is a type of soft soil. The Special Moment Resisting Frame System is designed so that the building has more strength to withstand earthquakes, especially the column structure. This building is classified as a high-level building, therefore the analysis of seismic load is carried out by Spectrum Response Dynamic, using the SRSS (Square Root of the Sum Squares) method because the building structure has far-flung natural vibration times. In high-rise buildings, it is necessary to control the displacement between floors to reduce the large sway on each floor. The displacement between floors resulting from elastic analysis is less than the maximum allowable intersection between floors. so that the building structure is still safe against swaying.
\end{abstract}

Keywords: SMRFS, Spectrum response dynamic, Displacement

\section{INTRODUCTION}

High-rise buildings design with seismic risk can be calculated using several methods, one of which is the Special Moment Resisting Frame System (SMRFS). Special Moment Resisting Frame System (SMRFS) is a skeletal system in structures with high ductility and is flexible. This skeletal system is planned for high seismicity prone areas with the D, E and $F$. seismic design categories.

In this final project, the planned building is an apartment building located in East Surabaya in soft soil conditions with spectral response values of Ss $0.66 \mathrm{~g}$ and $\mathrm{S}_{1} 0.24 \mathrm{~g}$. Seismic design categories obtained from the results of the spectral acceleration response design parameters obtained through the Indonesian Spectra Design website are included in category $\mathrm{E}$. With this, the 33-storey apartment building can be planned using a Special Moment Resisting Frame System (SMRFS).

\section{Bending Structure Component Planning}

In planning flexible structural components using the Special Moment Resisting Frame System method, it must fulfill several conditions set forth in SNI 2847:2013 ps 21.5, including:

1. Style and geometry requirements:

a. Pu factor press axial force must be less than $0,1 \mathrm{Agfc}^{\prime}$

b. The net span beam In must exceed $4 d$

c. The ratio of width and height of the beam should not be less than 0,3

2. Longitudinal reinforcement requirements: 
a. The area of reinforcement must be greater than the minimum reinforcement area and the reinforcement ratio $\rho$ must not exceed 0.025

b. The strength of positive and negative moments across the cross section along the structural components must not be less than a quarter of the maximum moment strength, where

$$
M n^{+} \geq 1 /{ }_{4} M n_{\text {maks }} \text { dan } M n^{-} \geq 1 / 4 M n_{\text {maks }}
$$

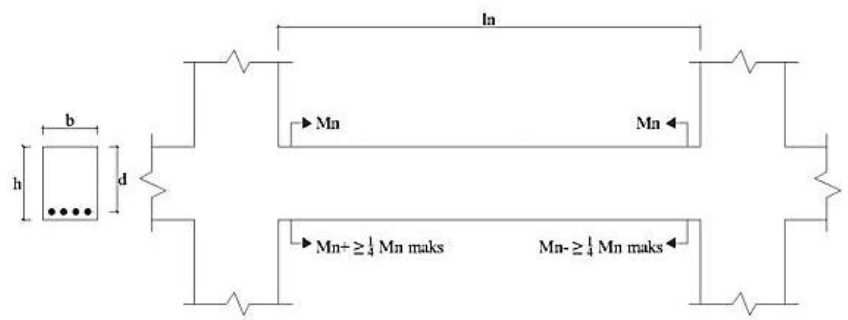

Figure 1. Longitudinal Moment Requirements

3. Transverse reinforcement:

The length of crossing distance should not exceed the smallest of $d / 4,6$ times the diameter of the reinforcement and must not be smaller than $150 \mathrm{~mm}$.

\section{Column Structure Planning}

In planning structural components subjected to bending loads and axial loads using the Special Moment Resisting Frame System method must meet the conditions set forth in SNI 2847: 2013 ps 21.6.

1. Requirements for style and geometry:

a. Pu factored press axial force must exceed0,1 Agfc'.

b. Column dimensions must not be less than $300 \mathrm{~mm}$.

c. The ratio of the width and height of the column must exceed 0,4.

2. Longitudinal reinforcement requirements:

a. The longitudinal reinforcement area must not be less than 0,01Agand should not be more than $0,06 \mathrm{Ag}$.

b. In columns with a rounded stirrup, the minimum number of longitudinal stems is 6 .

3. Transverse Reinforcement:

a. The length of the stirrup should not exceed the smallest of $h / 4,6$ times the diameter of the reinforcement and must not be smaller than the value of so, where so it should not be less than $100 \mathrm{~mm}$ or more than $150 \mathrm{~mm}$.

b. Total cross-sectional area of square stirrup reinforcement:

$$
\begin{aligned}
& \mathrm{A}_{s h}>0,3 \frac{s b_{c} f c^{\prime}}{f y t}\left[\left(\frac{A_{g}}{A_{s h}}\right)-1\right] \\
& \mathrm{A}_{\mathrm{sh}}>0,09 \frac{s b_{c} f c^{\prime}}{f y t}
\end{aligned}
$$

\section{Seismic Load Analysis}

Seismic load analysis is carried out by dynamic spectrum response. Based on SNI 1726: 2012 ps 7.9.3, in inputting spectrum response load there are two types of variants, namely CQC (Complete Quadratic Combination) which is used if the building structure has adjacent natural vibration times or the value difference is less than $15 \%$, and SRSS (Square Root of the Sum Squares), used if the building structure has a long natural vibration time. 


\section{METHODOLOGY}

\section{Research Data}

The research data describes the building to be studied, namely the ECC Mansion apartment building located in the city of Surabaya. This structure uses reinforced concrete material throughout the building. This building has a height of 142.9 meters. The function of this building is as a shopping area and residential area.

\section{Implementation of Research}

The steps taken in carrying out this final project are the initial stages of preparing research data, namely in the form of soil data, concrete quality data and steel quality, and architectural floor data. Conduct literature studies regarding the calculation of structures. The next stage is modeling the structure by planning the dimensions of the plates, beams, columns. Imposing structures in the form of dead loads, live loads and earthquake loads. Inner style analysis is carried out with the SAP 2000 assistance program. The last step is to calculate reinforcement structures and plan drawings.

\section{RESULTS AND DISCUSSION}

\section{Preliminary Design}

The ECC Mansion apartment building structure is assumed to be a pinch type to make it more resistant to earthquake forces. This structure uses repetitive concrete material throughout the building with 33 floors. The results of the dimensional design of the structural elements used in planning this apartment building are:

1. Beam Preliminary Design

The design of the beam dimensions produced from the calculation is numbered 7 pieces of different sizes.

2. Column Preliminary Design

There are 8 types of columns with different dimensions used in this planning, namely columns K1, K2, K3, K4, K5, K6, K7, K8.

3. Slab Preliminary Design

The floor plate in this building consists of one-way slab and two-way slab. Based on the calculation results of plate thickness used, namely S1 $(250 \mathrm{~mm}), \mathrm{S} 2(150 \mathrm{~mm}), \mathrm{S} 3(120$ $\mathrm{mm})$.

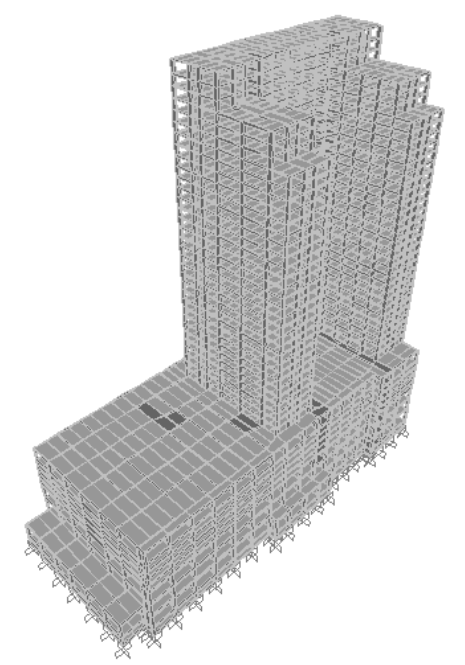

Figure 2. Preliminary Design 


\section{Earthquake Loading}

The planned apartment building is located in East Surabaya City with $S_{D S}=0.607$ and $S_{D 1}=0.498$ with soft soil conditions. The stages of earthquake loading include:

1. Categories of Building Risks and Mainstay Factors of Earthquakes

Based on SNI 1726: 2012 article 4.1.2, the structure of this building is categorized as risk II with earthquake priority factor $l_{e}=1$.

2. Earthquake Retention Structure System

Based on SNI Earthquake table 1726: 2012 article 7.2.2, for Special Moment Resisting Frame System parameter value $R=8, \Omega_{0}=3, C_{d}=5,5$.

3. Inter-Floor Deviation Control

Deviation value is taken from the results of the largest and most influential analysis of RSPX and RSPY earthquake forces with the data needed to determine the deviation, namely:

$$
\delta \mathrm{x}=\frac{\frac{\delta e . C d}{I e}}{\delta=\delta \mathrm{x}(\mathrm{n})-\delta \mathrm{x}(\mathrm{i})}
$$

Floor-level deviation limits $(\delta)$, due to earthquakes reviewed through elastic analysis may not exceed the permit level floor deviation $(\delta a)$, where the floor deviation limit for SRPMK is in accordance with SNI table 1726: 2013 article 7.9.2 which is calculated with $0.020 \mathrm{hsx}$. For the SMRFSstructure system with the E seismic design category, the limit of intersection between the permit level level must be calculated with $\delta a / \rho$ (redundation factor).

Table 1.Maximum Floor Deviation

\begin{tabular}{lccccc}
\hline & $\boldsymbol{\delta} \mathbf{e}(\mathbf{m})$ & $\boldsymbol{\delta} \boldsymbol{x}(\mathbf{m})$ & $\boldsymbol{\delta}(\mathbf{m})$ & $\boldsymbol{\delta} \mathbf{a} / \boldsymbol{\rho}(\mathbf{m}$ & note \\
$\mathrm{n}$ & & & & $\mathbf{j}$ & \\
$\mathrm{Y}$ & 0.205 & 1.128 & 0.011 & 0.056 & $\mathrm{OK}$ \\
$\mathrm{Y}$ & 0.2076 & 1.142 & 0.011 & 0.056 & $\mathrm{OK}$ \\
\hline
\end{tabular}

Earthquake Shear Force Control

Control of dynamic earthquake force structure functions to adjust the earthquake force according to SNI 1726: 2012 which has been inputted with the spectrum response method. The basic shear force is calculated by:

$$
\mathrm{V}=\mathrm{C}_{\mathrm{s}} \cdot \mathrm{W}
$$

Based on the results of the basic earthquake shear control in which the earthquake shear force resulting from the elastic analysis is greater than the planned $85 \% V$ earthquake force, the building structure meets the requirements for the basic shear force of the earthquake.

Table 2. Earthquake Shear Force Control

\begin{tabular}{ccccc}
\hline Arah & Static & Dynamic & $\mathbf{8 5 \% V}$ & Ket \\
\hline$X$ & 3284932,21 & 3462080,1 & 2792192, & OK \\
& & & 38 & \\
Y & 3284932,21 & 3491552,99 & 2792192, & OK \\
& & & 38 & \\
\hline
\end{tabular}

\section{Spectrum Response Dynamic Analysis}

Before setting the load for a spectrum response, the initial stage needed is to determine the type of spectrum response analysis In determining the type of spectrum response analysis, it is necessary to know the difference between the vibration periods in 
each mode $(\Delta T)$. Obtained $T$ results that exceed 15\%, then use the SRSS method for dynamic analysis of spectrum responses. Data inputted to SAP for dynamic analysis of spectrum response is $S s=0.668$ and $S_{1}=0.248 \mathrm{~g}$.

Data needed in loading for spectrum responses are:

Priority factor $(I)$ $=1$

Earthquake reduction factor $(R)$ $=8$

Scale factor of earthquake direction X, U1 $\left(\frac{I . R}{g}=\frac{1.9,81}{8}\right)$

$=1.22625$

Scale factor of earthquake direction $\mathrm{Y}, \mathrm{U} 2(30 \% \mathrm{X})$ $=0.367875$

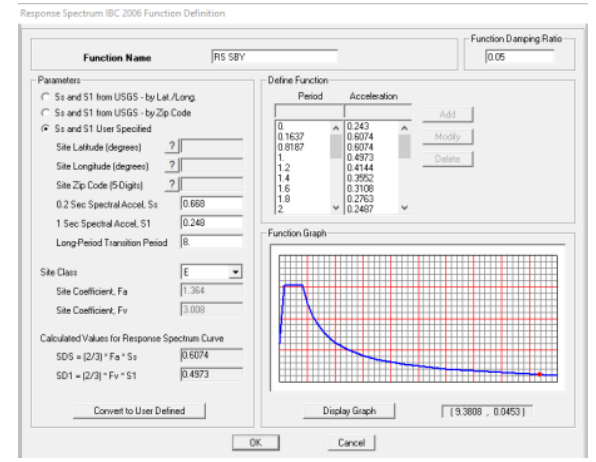

Figure 3.Spectrum Respons Input

\section{Calculation of Beam Structure}

The results of reinforcement beam Special Moment Resisting Frame System for the beam area were reviewed with a dimension of cross section dimensions of $400 \mathrm{~mm} \times 700 \mathrm{~mm}$ on the G floor, namely:

Table 3. Calculation of Beam Structure

\begin{tabular}{ccccc}
\hline Area & $\begin{array}{c}\mathbf{M u} \\
\mathbf{N m m}\end{array}$ & $\begin{array}{c}\mathbf{M n} \\
\mathbf{N m m}\end{array}$ & $\begin{array}{c}\mathbf{A s} \\
\mathbf{m m}^{2}\end{array}$ & Bars \\
\hline Left Beam & 54080273 & 67600341 & 3039,52 & $8 \mathrm{D} 22$ \\
& 1 & 3,8 & & \\
Middle & 31884275 & 39855344 & 1899,7 & $5 \mathrm{D} 22$ \\
Beam & 3 & 1,3 & & \\
Right Beam & 54443399 & 68054249 & 3039,52 & $8 \mathrm{D} 22$ \\
& 3 & 1,3 & & \\
\hline
\end{tabular}

Whereas for the transversal reinforcement of the beam from the calculation results generated reinforcement 13D - 100.

\section{Calculation of Column Structure}

The column in the area under review is $1000 \mathrm{~mm} \times 800 \mathrm{~mm}$. Calculation of column reinforcement is done with the pcaColumn program. 


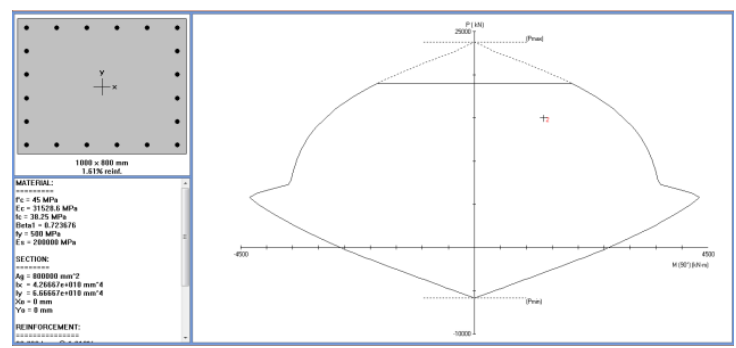

Figure 4. Calculation of Column Structure

Obtained results $\rho=0.0161$ from pcaColumn. Obtained Aspects of $13203.7 \mathrm{~mm} 2$. Then a longitudinal reinforcement is installed for column 20D 29. The transversal reinforcement column generated from the area other than the span is D13-150. The transverse reinforcement along the lo as the column support area is calculated by the equation:

$$
\begin{gathered}
\text { Ash }=0,3 \frac{s h c f c^{\prime}}{f y t}\left[\left(\frac{A g}{A c h}\right)-1\right] \\
\text { Ash }=0,09 \frac{s h c f c^{\prime}}{f y t}
\end{gathered}
$$

The transverse reinforcement results are calculated along the above equation, which is 6D13 - 100. The calculated stirrup is needed along the lo which is in the column support area, the length of $l o$ is determined by the largest value between: $450 \mathrm{~mm}$, height of the structural element in the joint area $=800 \mathrm{~mm}$, and $1 / 6$ column height $=908.3 \mathrm{~mm}$. From these results a lo value of $908.3 \mathrm{~mm}$ was taken.

\section{CONCLUSION}

Based on the results of internal force analysis through the SAP 2000 program and the results of manual calculations that have been carried out referring to the concrete SNI 2847: 2012 and SNI earthquake 1726: 2012, then obtained some conclusions including the following:

1. Through SPT data, the results of the average NSPT are obtained at $6.59<15$, then the type of soil in the building area includes the SE soft soil type.

2. Based on the results of the basic earthquake shear control, the structure is safe enough to withstand the shear forces of the earthquake due to the shear force of the earthquake, $\mathrm{Vt}$ generated from the structure analysis still exceeds 0.85 from the base shear force $V=$ Cs.W

3. Floor deviation limits for Special Moment Resisting Frame with the category of seismic design $\mathrm{E}$ must be calculated with $\delta a / \rho$, where the results of inter-floor deviation are $\delta$ less than the boundary between the floor deviation of the permit level $\delta a / \rho$, then based on the floor-level deviation of that level, safe structure for displacement due to earthquake forces.

4. Calculation of structural dimension recapitulation for beam components are: B5080, B5070, B4050, B3040, B4070, B3060, B4060, B3050, B4080.

5. Calculation of recapitulation of structural dimensions for column components, namely:K120/80, K150/70, K 80/80, K120/60, K150/60, K135/60, K120/50, K150/60, K135/60, K110/60, K100/80.

6. Calculation of plate thickness recapitulation for this apartment structure are $S 1$ (LG) 250 mm, S2 (Podium) 150 mm, S3 (Apartment) 120 mm

\section{REFERENCES}


Bagio, T. H., \& Tavio. (2018). Dasar - Dasar Beton Bertulang. Surabaya: Penerbit ANDI.

BSN. (2012). Tata Cara Perencanaan Ketahanan Gempa Untuk Struktur Bangunan Gedung dan Non Gedung SNI 1726:2012. Badan Standar Nasional.

BSN. (2013). Persyaratan Beton Struktural Untuk Bangunan Gedung SNI 2847:2013. Badan Standar Nasional.

BSN. (2013). Beban Minimum Untuk Perancangan Bangunan Gedung dan Struktur Lain SNI 1727:2013. Badan Standar Nasional.

Departemen Pekerjaan Umum. (1987). Pedoman Pembebanan Indonesia Untuk Gedung PPPURG 1987. Departemen Pekerjaan Umum.

Laksono, \& Ricky. (2010). Perencanaan Struktur Gedung Rusunawa UNIMUS. Semarang.

Pawirodikromo, Widodo. (2012). Seismologi Teknik dan Rekayasa Kegempaan. Yogyakarta: Pustaka pelajar.

PUSKIM PU. (2011). Retrieved Maret 20, 2019, from Desain Spektra Indonesia: http://puskim.pu.go.id/Aplikasi/desain_spektra_indonesia_2011

Widodo, \& Fauziah, R. (2013). Analisis Gaya Gempa Rencana Pada Struktur Bertingkat Banyak Dengan Metode Dinamik Respon Spektra. Yogyakarta: Konferensi Nasional Teknik Sipil. 